\title{
COMMON FOREIGN AND SECURITY POLICY AND EUROPEAN SECURITY AND DEFENCE POLICY AFTER THE LISBON TREATY: OLD PROBLEMS SOLVED?
}

\begin{abstract}
Julia Schmidt*
Summary: In its aim to become a global security actor, the EU is increasingly undertaking civilian and military crisis missions all over the world. These missions are based on the European security and defence policy (ESDP) which forms an integral part of its common foreign and security policy (CFSP). The Treaty of Lisbon seems to mirror the Union's global security ambitions as it addresses the European security and defence policy in a whole new treaty section. However, European missions still depend on willing Member States to make civilian and military capabilities available to the Union for the implementation of its security and defence policy. The purpose of this article is to examine the relationship between the European Union and the Member States in the field of the common foreign and security policy and the European security and defence policy and whether the Treaty of Lisbon manages to clarify the situation. What constraints, if any, do the common foreign and security policy and the European security and defence policy impose on the Member States regarding the conduct of their national foreign policy? The article argues that the relationship between the EU and the Member States can only be determined after an examination of the binding nature of primary and secondary CFSP law as well as of international agreements concluded by the Union.
\end{abstract}

\section{Introduction}

In its aim to become a global security actor, the EU is increasingly undertaking civilian and military crisis missions all over the world. These operations include police missions, ${ }^{1}$ rule of law missions, ${ }^{2}$ border assistance missions, ${ }^{3}$ missions in support of security sector reforms, ${ }^{4}$ monitor-

\footnotetext{
* PhD candidate, University of Edingburgh.

1 See for example EU Police Mission in Afghanistan, EUPOL AFGHANISTAN, Council Joint Action 2008/229/CFSP of 17 March 2008.

2 See for example the EU rule of law mission in Kosovo, EULEX KOSOVO, Council Joint Action 2008/124/CFSP of 4 February 2008.

3 See for example the EU Border Assistance Mission at Rafah Crossing Point in the Palestinian Territories EU BAM Rafah, Council Joint Action 2007/359/CFSP of 23 May 2007.

4 See for example the EU mission in support of security sector reform in Guinea-Bissau, EU SSR Guinea-Bissau, Council Joint Action 2008/112/CFSP of 12 February 2008.
} 
ing missions ${ }^{5}$ and military missions, ${ }^{6}$ and are based on the European Union's security and defence policy (ESDP) ${ }^{7}$ which forms an integral part of its common foreign and security policy (CFSP). The function of the European security and defence policy is to make the common foreign and security policy operational. One of the motives for the drafting of the Treaty of Lisbon was to enhance the coherence and effectiveness of the Union's external action and in particular to provide the EU with the military capability to implement its civilian aims and objectives. At first glance, the Treaty of Lisbon seems to mirror the Union's global security ambitions, as it is expands the range of the so-called 'Petersberg tasks'. Joint disarmament operations, military advice and assistance tasks, conflict prevention and peace-keeping tasks as well as post-conflict stabilisation are added ${ }^{8}$ to the already possible humanitarian and rescue tasks, peace-keeping tasks and tasks of combat forces in crisis management, including peacemaking. ${ }^{9}$ Furthermore, the Treaty of Lisbon addresses the European security and defence policy in a whole new treaty section, putting more emphasis on its scope. In consequence, the European Union appears to be more prepared than ever to take on responsibility on the international scene in order to promote democracy, the rule of law and respect for human rights. However, European missions still depend on the Member States making civilian and military capabilities available to the Union for the implementation of its security and defence policy (Article 42 (3) TEU Lisbon version). Thus, the effectiveness and efficiency of the EU's external action depends on the Union's relationship with its Member States.

The purpose of this paper is to examine the relationship between the European Union and the European Member States in the field of the common foreign and security policy and the European security and defence policy and whether the Treaty of Lisbon manages to clarify the situation. What constraints, if any, do the common foreign and security policy and the European security and defence policy impose on the Member States regarding the conduct of their national foreign and security policy? Related to this overall problem are several sub-questions. Is the CFSP purely intergovernmental? Are the Member States just utilising the CFSP structure to pursue their domestic policies? Has there been some

\footnotetext{
5 See for example Aceh Monitoring Mission (AMM), Council Joint Action 2005/643/CFSP of 9 September 2005.

6 See for example operation EUFOR in Chad, Council Joint Action 2007/677/CFSP of 15 October 2007.

7 The Treaty of Lisbon will rename the European security and defence policy as the common security and defence policy.

8 Article 43 (1) TEU Lisbon version.

9 Article 17 TEU Nice version.
} 
transfer of power from the Member States to the European Union? Has the CFSP developed into more than just the sum of the Member States? Have the Member States become semi-sovereign subjects? The answers to these questions are not identical, but they will help in approaching the overall problem of whether the Member States are constrained by the EU in the sphere of the CFSP and the ESDP.

The main emphasis of the paper is on an examination of the common foreign and security policy. This is due to the fact that the European security and defence policy forms an integral part of the common foreign and security policy. The European security and defence policy does not have its own instruments to pursue its aims and objectives and therefore has to rely on the instruments of the Union's common foreign and security policy. Furthermore, ESDP missions have to be in line with the overall objectives and principles of the CFSP. ${ }^{10}$ The main argument of the paper is that the relationship between the European Union and the Member States in the sphere of the common foreign and security policy, as well as in the sphere of the European security and defence policy, has to be determined through an analysis of the binding nature of primary and secondary CFSP law as well as of international agreements concluded by the European Union. As these treaty provisions are the same for the common foreign and security policy and the European defence and security policy, the paper argues that the relationship between the European Union and the Member States in the sphere of the common foreign and security policy and the European security and defence policy is the same.

In order to examine if the European Member States are constrained by the common foreign and security policy in the conduct of their national foreign policy, the next section will discuss if it is useful to approach this problem by asking if the common foreign and security policy is purely intergovernmental soft law. One could argue that if the common foreign and security policy has stopped being purely intergovernmental, the Member States must have transferred some of their powers to the Union. In consequence, the Union must have developed into more than just the sum of its Member States and they have to be constrained by the common foreign and security policy. The third section will analyse if the attribution of the European Union with international legal personality could indicate that there has been some transfer of powers from the Member States to the EU. The fourth section will examine whether primary and secondary CFSP law is binding on the Member States. Special emphasis will be put on the principles of systematic cooperation and loyal

10 M Ortega, 'Beyond Petersberg Missions for the EU Military Forces' in N Gnesotto (ed), EU Security and Defence Policy: The First Five Years (1999-2004) (Institute for Security Studies, European Union, Paris 2004) 76. 
cooperation, as well as on joint actions and common positions. The last part will focus on the constraints international agreements concluded by the European Union might impose on the Member States.

\section{CFSP as purely intergovernmental soft law?}

Usually, the common foreign and security policy and the European security and defence policy under the Nice Treaty are described as intergovernmental in nature, ${ }^{11}$ in contrast to the supranational European Community. But what is the label 'intergovernmental' supposed to indicate? It usually refers to the method that led to the creation of the CFSP. The common foreign and security policy that developed outside the treaty framework and became legalised through the Treaty of Maastricht started as a form of intergovernmental cooperation between the Member States. In the high-political field of foreign and security policy, the European Member States chose to work together but they have not been willing to transfer their sovereignty and use the Community law method. Using a legal framework based on international law did not seem to threaten their sovereign powers. ${ }^{12}$ In the context of the European Union, the term 'intergovernmental' is used not only to refer to the origins of the common foreign and security policy but to stress the differences between the common foreign and security policy and the supranational European Community. ${ }^{13}$ Although there are several views on what constitutes a supranational system, ${ }^{14}$ they usually include the capacity for autonomous decision making, the capacity to adopt legally binding rules by qualified majority voting, judicial enforcement mechanisms and parliamentary control, as well as financial autonomy. ${ }^{15}$ One of the key elements that turn the European Community into a supranational system has been the transfer of sovereignty from the Member States to the Community. Some who describe the CFSP as intergovernmental soft law thus use the term to indicate that the European Member States are not constrained in the conduct of their national foreign policy by the CFSP, as a transfer of sovereignty to the European Union would never have taken place. Implied in this statement is the view that the CFSP is purely governed by the

\footnotetext{
11 See for instance W Wagner, 'Why the EU's Common Foreign and Security Policy Will Remain Intergovernmental: A Rationalist Institutional Choice Analysis of European Crisis Management Policy' (2003) 10:4 Journal of European Public Policy 589; E Denza, The Intergovernmental Pillars of the European Union (Oxford University Press, Oxford 2002).

12 E Denza, The Intergovernmental Pillars of the European Union (Oxford University Press, Oxford 2002) 5.

13 M R Eaton, 'Common Foreign and Security Policy' in D O'Keeffee and P M Twomey (eds), Legal Issues of the Maastricht Treaty (Chancery Law Publishing Ltd, Chichester 1994) 216.

14 G Bono, 'Some Reflections on the CFSP Legal Order' (2006) 43 CML Rev 357.

15 See Bono (n 14) 357.
} 
working methods and principles of general international law. ${ }^{16}$ The term 'soft law' in this context is used to indicate that Union competence in the sphere of the CFSP does not exist and that the CFSP forum is used by the Member States to exercise their national foreign and security competences. Those who recognise a change in the nature of the CFSP might look for supranational elements in the overall intergovernmental CFSP ${ }^{17}$ and argue that the CFSP stopped being purely intergovernmental.

However, it is doubtful whether labelling the CFSP as purely-intergovernmental, intergovernmental or as soft law adds much value to the examination of the Union's relationship with its Member States. The development of the CFSP started in intergovernmental conferences and even today it is driven by an intergovernmental setting. The European Council defines the principles and general guidelines of the CFSP (Article 13 TEU Nice version). Secondary CFSP provisions are adopted by the Council (Articles 14, 15 TEU Nice version). Nevertheless, an intergovernmental setting does not necessarily lead to the outcome of these meetings being of an intergovernmental nature. Besides, the term intergovernmental cannot denote a non-biding character as such. Although international law largely lacks enforcement mechanisms and is thus often labelled soft law in contrast to hard law, international law is still law after all. ${ }^{18}$ Furthermore, no agreement exists on how soft law should be defined. Some claim that soft law is non-law ${ }^{19}$ while others assume that soft law can be found at the mid point of two extremes, between hard law and purely political arrangements, and that many varieties of soft law exist. According to the latter view, soft law is the result of legal arrangements that have been weakened along at least one of the dimensions of obligation, precision and delegation. ${ }^{20}$ Overall, qualifying the common foreign and security policy as soft law or as intergovernmental does not add much value in answering the question whether the Member States are constrained by the common foreign and security policy. In fact, it represents a different type of argument, looking at the decision-making process and not at the binding legal character of the common foreign and security policy. The latter problem, which can only be solved by interpreting the provisions of the common foreign and security policy itself, is the focus of this paper.

\footnotetext{
16 See Bono (n 14) 338.

17 See Wagner (n 11) 585, 589.

18 The obligatory nature of international law is sometimes based on the theory of natural law, on consent or on socialist theory, for example. See K Ipsen, Völkerrecht $\left(5^{\text {th }}\right.$ edn $\mathrm{CH}$ Beck, München 2004) 7-17.

19 D Shelton, 'Law, Non-Law and the Problem of "Soft Law"' in D Shelton (ed), Commitment and Compliance: The Role of Non-Binding Norms in the International Legal System (Oxford University Press, Oxford 2000) 4.

20 KW Abbott and D Snidal, 'Hard and Soft Law in International Governance' (2000) 54 International Organization 422.
} 
Hence, the question should not to be whether the CFSP represents intergovernmental soft law, but rather to what extent the common foreign and security policy is binding and what the nature of its binding character is: is it binding in a legal sense or in a political sense, or is it binding in both senses? If the CFSP is binding on the Member States, they must be constrained in the conduct of their national foreign policy. They must have transferred some of their powers to the Union in the field of common foreign and security policy which in turn has developed into more than just the sum of its Member States. However, one has to bear in mind that the possible conclusion that the common foreign and security policy is binding on the Member States does not necessarily lead to the common foreign policy being supranational.

\section{Legal personality of the European Union}

The legal personality of the European Union could speak in favour of the argument that the European Union is more than just the sum of its Member States and that the Member States are constrained by the EU in the field of CFSP as some transfer of power must have taken place. Legal personality is conceived as the ability to exercise certain rights and to fulfil certain obligations. ${ }^{21} \mathrm{~A}$ legal person is independent of its members and acts through its organs. These organs have the ability to issue norms and rules. ${ }^{22}$ If the European Union could be qualified as a legal person, it would have to be distinct from its Member States. Hence, they must have transferred some of their powers to the Union as otherwise it would not possess the capacity to create rights and obligations.

It is important to distinguish legal personality from legal capacity. The former refers to being a subject of international law, whereas the latter describes what the legal entity is entitled to do. ${ }^{23}$ Only states as born subjects of international law enjoy general legal capacity. International organisations, on the other hand, can have legal personality. ${ }^{24}$ If they do, their legal capacity is, however, circumscribed by the competences the states have created for them in their founding treaties. ${ }^{25}$ In contrast to

\footnotetext{
${ }^{21}$ R Wessel, 'The Inside Looking Out: Consistency and Delimitation in EU External Relations' (2000) 37 CML Rev 1140.

22 D Curtin, I Dekker, 'The EU as a "Layered" International Organization: Institutional unity in Disguise' in P Craig and G de Burca (eds), The Evolution of EU Law (Oxford University Press, Oxford 1999) 95.

23 RA Wessel, 'The International Legal Status of the European Union' (1997) 2 European Foreign Affairs Review 111.

24 D Verwey, The European Community, the European Union and the International Law of Treaties: A Comparative Legal Analysis of the Community and the Union's External TreatyMaking Practice (TMC Asser Press, The Hague 2004) 59.

25 See Wessel (n 23) 111.
} 
states, they do not have the competence to create and invent new competences for themselves.

The Treaty of Lisbon, merging the pillars of the European Union and leading to the replacement of the European Community with the European Union (Article 1 TEU Lisbon version) now states that the 'Union shall have legal personality' (Article 47 TEU Lisbon version). But one can wonder if the Treaty of Lisbon is granting international legal personality to the European Union in the field of common foreign and security policy for the first time or if it is merely formalising the Union's implied legal personality. The Treaty of Nice makes no explicit reference to the legal personality of the European Union. As the EC Treaty entails special provisions in respect of the European Community's internal (Article 282 EC) as well as its international legal personality (Article 281 EC Treaty), one could deny the legal personality of the European Union as an actus contrarius argument.

In order to assess whether the European Union can be attributed with international legal personality that is independent of the legal personality of the European Communities, ${ }^{26}$ two questions have to be distinguished. The question whether the EU could enjoy independent legal personality depends on the systematic relationship between the different pillars of the European Union. Three scenarios are possible. The pillars could either form a complete unity ${ }^{27}$ or they could be completely separate from each other. Lastly, the Union could form a legal entity with legal sub-systems. ${ }^{28}$ According to the unity thesis, the European Union would be one single organisation with one legal personality ${ }^{29}$ and hence the EU could not be attributed with international legal personality that is independent of the legal personality of the European Communities. However, if the EC and EU treaties formed separate orders or if they formed legal sub-orders of one legal system, the EU could still enjoy independent legal personality. Those who argue in favour of the European Union being a single legal system, ${ }^{30}$ consisting of all the treaties and secondary law, ${ }^{31}$

\footnotetext{
26 EC and Euratom.

27 A von Bogdandy, 'The Legal Case for Unity: The European Union as a Single Organization with a Single Legal System' (1999) 36 CML Rev 889; A von Bogdandy and M Nettesheim, 'Ex Pluribus Unum: Fusion of the European Communities into the European Union' (1996) 2 ELJ 268.

28 D Curtin, I Dekker, "The EU as a "Layered" International Organization: Institutional Unity in Disguise' in P Craig and G de Burca (eds), The Evolution of EU Law (Oxford University Press, Oxford 1999) 86.

29 See von Bogdandy and Nettesheim (n 27) 284.

30 See von Bogdandy (n 27) 268; A Tizzano, 'The Foreign Relations Law of the EU Between Supranationality and Intergovernmental Model' in E Canizzaro (ed), The European Union as an Actor in International Relations (Kluwer Law International, The Hague 2002) 144.

31 See von Bogdandy (n 27) 887.
} 
usually refer to the Airport Transit Visa case ${ }^{32}$ in which the ECJ found itself to be competent to annul a TEU measure insofar as it encroached upon Community competences. ${ }^{33}$ However, the unity thesis fails to explain the different roles of the institutions played under the pillars, for example, and thus has to be rejected. On the other hand, the theory of strict separation of the pillars cannot explain the reference to the single institutional framework of the Union (Article 3 TEU) and the amendment of the Treaties and accession to the Union as a whole (Articles 48, 49 TEU). ${ }^{34}$ Only the theory that regards the European Union as one legal entity consisting of legal sub-systems seems to be capable of avoiding the obstacle the other two extreme positions face. Hence, the European Union contains two legal personalities - namely the EC and Euratom. Each legal sub-system is guided by its own rules and procedures, and the European Union could be attributed with international legal personality that is independent of the legal personality of the European Communities. Whether or not the European Union enjoys international legal personality will be examined below.

The EU could be an international legal person if it were granted competences that can only be inherited by an international legal person, ${ }^{35}$ as established in the Reparation for Injuries case ${ }^{36}$ by the ICJ. Such functions could include the conclusion of agreements. Since the Treaty of Amsterdam, the Union has the capacity to conclude international agreements. As Article 24 TEU has to be interpreted in connection with Article 18 (I) TEU, stating that the Presidency represents the Union and not the Member States, agreements of Article 24 TEU are concluded by the EU itself and not by the Council on behalf of the Member States ${ }^{37}$ So far, the Council has concluded three types of international agreements in relation to the conduct of ESDP missions, including the status of mission and status of force agreements with the host state, agreements with third parties, contributing personnel or assets and finally agreements regulating the exchange of information. ${ }^{38}$ As a consequence of its treaty-making

32 Case C-170/96 Commission v Council [1998] European Court Reports I-2763.

33 C Herrmann, "Much Ado about Pluto? The "Unity of the Legal Order of the European Union" Revisited' in M Cremona and B De Witte (eds), EU Foreign Relations Law: Constitutional Fundamentals: Essays in European Law (Hart Publishing, Oxford and Portland, Oregon 2008) 26.

34 See C Herrmann (n 33) 25; A Tizzano (n 30) 143.

35 D McGoldrick, International Relations of the EU (Longman, London and New York 1997) 37.

36 Reparation for Injuries (1949) ICJ Rep 174.

37 P Eeckhout, External Relations of the European Union: Legal and Constitutional Foundations (Oxford University Press, Oxford 2004) 158-159.

38 A Sari, 'The Conclusion of International Agreements by the European Union in the Context of the ESDP' (2008) 57 ICLQ 55. 
power, objective reality suggests that the EU already has implied international legal personality. Legal personality does not depend on recognition by others. ${ }^{39}$ Hence, the Lisbon Treaty is merely formalising the EU's legal capacity to act.

But can the legal personality of the European Union really support the thesis that the European Union in the sphere of the common foreign and security policy is more than just the sum of its Member States and that the Member States might be constrained by the Union? Declaration No 24 annexed to the Lisbon Treaty, concerning the legal personality of the European Union, mirrors the fear of the Member States that the granting of legal personality to the Union could amount to a loss of sovereignty, as it states that the Union's 'legal personality will not in any way authorise the Union to legislate or to act beyond the competences conferred upon it by the Member States in the Treaties'. However, the general capacity of the European Union to have rights and to be under obligations is a necessary, although not sufficient, element to argue in favour of the possibility that the EU is more than just the sum of its Member States and that the Member States could be constrained by the Union in the field of the CFSP. The legal personality of the European Union is merely the first step to argue that the Union is an entity distinct from its Member States. However, even if the EU can be seen as an entity vis-à-vis its Member States, this does not answer the question about if or when the Member States are constrained by the CFSP. The legal personality of the European Union merely indicates that it has the capacity to have rights and to be under obligations in general, but it does not indicate which competences it has in reality. The European Union can only have competences that have been either explicitly attributed to it through the founding treaty or according to the doctrine of implied powers. However, implied powers only exist when they are necessary for the exercise of express powers. ${ }^{40}$

Furthermore, the creation of an international organisation and the attribution of this organisation with certain competences do not necessarily imply that the members of this organisation have completely transferred some of their powers or competences to this organisation and are now prevented from exercising these powers themselves. One could think of two alternatives. First, the members could have created parallel competences for this organisation or, second, they could have delegated the exercise of these competences to this organisation without losing their

\footnotetext{
39 R Higgins, Problems and Process: International law and how we use it (Oxford University Press, Oxford 1994) 47, 48.

40 Dissenting opinion by Judge Hackworth, Reparation for Injuries (1949) ICJ Rep 174, 198.
} 
own competences. That the latter scenario is usually the case can be illustrated by the unique case of the European Community. The Member States transferred some of their sovereignty to the Community and are no longer competent to act in areas where the EC has acquired exclusive competence. The Community institutions in turn can adopt binding decisions. These criteria have contributed to the supranational character of the European Community which is the only supranational international organisation so far. But even if one claimed that by creating the European Union and the CFSP the Member States have transferred some of their sovereignty to the EU, it would still be necessary to analyse what aspects of their sovereignty have been transferred. The finding that the EU has legal personality and thus can create rights and obligations in theory does not specify which rights and obligations it has in reality ${ }^{41}$ as this is a question of the scope of the legal capacity of the Union in the sphere of the common foreign and security policy.

In sum, the explicit granting of legal personality to the European Union in the Treaty of Lisbon does not bring us any closer to answering the question whether the European Member States are constrained by the Union's common foreign and security policy or the European security and defence policy. It can merely serve as a positive signal to the global community regarding the Union's capability to act. ${ }^{42}$ The question whether the Member States are constrained by the common foreign and security policy can only be answered by analysing the binding nature of primary and secondary CFSP provisions and international agreements concluded by the Union in the sphere of the CFSP.

\section{The binding nature of CFSP law}

The following section examines whether the Member States are bound by the Union's common foreign and security policy. The first part looks at primary CFSP law, highlighting the principles of systematic cooperation and the principle of loyal cooperation. The next part focuses on secondary CFSP provisions with its main focus on decisions formerly known as joint actions and common positions. The constraints that international agreements concluded by the Union might impose on the Member States are analysed in part three.

\footnotetext{
41 E Paasivirta, 'The European Union: From an Aggregate of States to a Legal Person?' (1997) 2 Hofstra Law \& Policy Symposium 54.

42 W Wessels and F Bopp, 'The Institutional Architecture of CFSP after the Lisbon Treaty Constitutional Breakthrough or Challenges Ahead?' (2008) Research Paper No 10 Challenge - The Changing Landscape of European Liberty and Security <http://www.ceps.eu $>11$.
} 


\section{A. The binding nature of primary CFSP law}

An analysis of the binding nature of primary EU law will focus on the principle of systematic cooperation and the principle of loyal cooperation. The Treaty of Lisbon introduces some modest changes in respect of these principles.

\section{The principle of systematic cooperation}

The principle of systematic cooperation states that the Member States 'shall consult one another within the European Council and the Council on any matter of foreign and security policy of general interest in order to determine a common approach' (Article 32 TEU Lisbon version). The wording of Article 32 TEU, like the wording of Article 16 TEU Nice version indicates through the use of the word 'shall' that the Member States are under the obligation to inform and consult each other. One of the minor changes Article 32 TEU will bring is the removal of the explicit obligation for the Member States to inform one another on any matter of general interest. However, as consultation between the Member States is only possible after information has taken place, the obligation to inform seems to be contained in the obligation to consult each other. Thus, the scope of the principle of systematic cooperation has not been limited by the Treaty of Lisbon.

What does the obligation of consultation entail? In international law, the obligation of consultation comprises the duty to avoid a position being taken before the matter has been discussed with the other partners. ${ }^{43}$ Article 32 TEU does not indicate any deviation from this concept of consultation. As a result, the principle of systematic cooperation as expressed in Article 32 TEU entails the negative obligation for the Member States not to go public with a domestic position on CFSP matters of general interest before the matter has been discussed within the CFSP framework first. ${ }^{44}$ This interpretation of Article 32 TEU is supported by the systematic relationship with Article 24 (3) TEU, entailing the principle of loyal cooperation, which will be addressed in the next section.

But in what circumstances are the Member States under the obligation to consult each other? Matters of foreign and security policy of 'general interest' seems to be a very broad category. General interest supposedly goes beyond purely national interests. But who defines what general interest is? The wording of Article 32 sentence 1 TEU, like the old

43 C Hillion and R Wessel, 'Restraining External Competences of EU Member States under CFSP' in M Cremona and B De Witte (eds), EU Foreign Relations Law: Constitutional Fundamentals: Essays in European Law (Hart Publishing, Oxford and Portland, Oregon, 2008) 82.

${ }^{44}$ See Hillion and Wessel (n 43) 82. 
interpretation of Article 16 TEU Nice version suggests that it is defined by the Member States, which would therefore limit the content of the obligation. ${ }^{45}$ However, in contrast to Article 16 TEU Nice version, which states that the duty to inform and to consult exists in order to ensure that the Union's influence is exerted as effectively as possible by means of concerted and convergent action', Article 32 TEU now contains the sentence that the Member States 'shall ensure, through the convergence of their actions, that the Union is able to assert its interest and values on the international scene'. The new wording, probably in line with the granting of legal personality to the EU (Article 47 TEU Lisbon version), thus speaks in favour of determining matters of foreign and security policy of general interest not from the perspective of the Member States but from the perspective of the European Union. The Lisbon Treaty therefore stresses the importance of the principle of systematic cooperation. However, as the Member States in practice can still prevent topics from being placed on the agenda of the Union, the impact of the new wording will be limited. In sum, when a topic of foreign and security policy of general interest to the Union is concerned, the Member States are not free to act as they please but are under the obligation to consult one another in the forum of the Union in order to ensure a common approach.

\section{The principle of loyal cooperation}

Related to the principle of loyal cooperation, Article 24 (3) TEU Lisbon version repeats in its first part the wording of Article 11 (2) TEU Nice version and is more specific than the general obligation for Member States to fulfil treaty obligations and to observe the principle of sincere cooperation as expressed in Article 4 (3) TEU Lisbon version. ${ }^{46}$ Article 24 (3) TEU Lisbon version lays down that the Member States

shall support the Union's external and security policy actively and unreservedly in a spirit of loyalty and mutual solidarity and shall comply with the Union's action in this area. The Member States shall work together to enhance and develop their mutual political solidarity. They shall refrain from any action which is contrary to the interests of the Union or likely to impair its effectiveness as a cohesive force in international relations.

Through the use of the term 'shall', the wording indicates that the Member States are obliged to act loyally and to cooperate. The mandatory character is underlined through the requirement that the Member States have to support the Union's policy 'actively' and 'unreservedly'.

\footnotetext{
45 See Hillion and Wessel (n 43) 81.

46 See Wessels and Bopp (n 42) 12.
} 
The loyalty obligation involves a positive as well as a negative obligation. The positive obligation asks the Member States to actively work together to enhance and develop the Union's external and security policy. The negative obligation requests the Member States to refrain from any action which runs counter to the interests of the EU or which is likely to infringe its effectiveness. The only innovation in relation to the principle of loyal cooperation through the Lisbon Treaty is the amendment that the Member States 'shall comply with the Union's action' in the area of external and security policy (Article 24 (3) TEU Lisbon version). However, this amendment relates to the already expressed positive as well as negative obligations of the Member States in the context of loyal cooperation, without giving them a new meaning but rather putting more emphasis on their importance. In sum, the loyalty obligation as expressed in the Lisbon Treaty thus stresses the Member States' obligation to respect the Union's CFSP acquis and to refrain from unilateral action that could undermine the Union's common foreign and security interests.

In comparison with the Treaty of Nice, the Lisbon Treaty introduces modest changes in respect of the principle of systematic cooperation and the loyalty obligation. Nevertheless, the changes that have been made put more emphasis on the need for the Member States to consider the Union's common foreign and security policy before they undertake their domestic foreign policy. The real significance of the binding nature of primary CFSP provisions will become visible in conjunction with secondary CFSP provisions. When the Member States reach a solution in the Council, and the Council adopts a Union decision, the principle of systematic cooperation and the loyalty obligation underline and enhance the Member States' obligation to conduct their national foreign policy in line with the Union's common foreign and security policy. In other words, the Member States are constrained in the conduct of their national policy by secondary CFSP provisions in conjunction with the principles of primary CFSP law. In this respect, the principle of loyal cooperation, containing the positive obligation for the Member States to actively support the Union's foreign and security policy, as well as the negative obligation to refrain from any action that might run counter to the Union's CFSP acquis, seems to be of greater significance than the principle of sincere cooperation that asks the Member States to consult one another in order to ensure a Union decision. The next part goes on to assess the binding nature of secondary CFSP provisions.

\section{B. The binding nature of secondary CFSP law}

In order to pursue the objectives of a common foreign and security policy, the Treaty of Nice mentions five different instruments, consisting 
of the definition of the principles of and general guidelines for the common foreign and security policy, common strategies, joint actions, a common position and the strengthening of systematic cooperation between the Member States (Article 12 TEU Nice version). Over the past few years, practice has also led to the development of decisions sui generis. Additionally, there is the possibility of the conclusion of international agreements (Article 24 TEU Nice version). The Lisbon Treaty introduces some modest changes. The instruments to implement the CFSP do not include common strategies. The terms common positions and joint actions have been deleted but the instruments as such still exist. The next section examines if secondary CFSP provisions are binding on the Member States. The emphasis will be on joint actions and common positions.

\section{Joint actions / Council decisions defining actions to be undertaken by the Union}

The Lisbon Treaty replaces the instrument of joint actions that 'shall address specific situations where operational action by the Union is deemed to be required' (Article 14 TEU Nice version) with Council decisions where 'the international situation requires operational action' (Article 28 TEU Lisbon version). In order to find out whether Council decisions defining actions to be undertaken by the Union are legally binding, the wording of Article 28 TEU, its systematic context, and its underlying rationale have to be analysed. The wording of Article 28 TEU Lisbon version only slightly deviates from the wording of Article 14 TEU Nice version. According to Article 28 (2) TEU, joint actions shall commit the Member States in the position they adopt in the conduct of their activity. The use of the word 'shall' indicates the binding character in respect of the Member States and their conduct of national foreign policy. This reasoning is supported by the systematic relationship of Article 28 (2) TEU with paragraph 1 , second subparagraph, and paragraphs 4 and 5 of the same Article. Paragraph 1, subparagraph 2 states that even when there has been a substantial change of circumstances underlying such a decision, "the Council shall review the principles and objectives of that decision and take the necessary decisions'. Thus, it is for the Council to adopt a new decision and until then the Member States are bound by the old decision. It is in this respect that the Treaty of Nice is more supportive of the binding nature of joint actions than the Treaty of Lisbon, as Article 14 (2) TEU Nice version states that the joint action shall stand as long as the Council has not acted. However, the wording of Article 28 TEU is still clear enough to conclude that Article 28 (1) subparagraph 2 TEU does not allow the Member States to invoke a radical change of circumstances in order to pursue their national foreign policy. Instead, it is for the Council to decide what should be done. However, paragraph 4 allows a Member 
State, in the case of imperative need arising from a change in situation and after failing to obtain a new Council decision, to take necessary measures as a matter of urgency, accompanied by the duty of immediately informing the Council. Apart from this provision which seems to be the only exception from the binding nature of an operational decision, ${ }^{47} \mathrm{a}$ Member State facing difficulties in implementing a joint action is asked to address the Council in order for it to seek an appropriate solution (Article 28 (5) TEU). In sum, the wording of Article 28 (2) TEU and its systematic context suggests the binding nature of operational decisions in respect of the Member States.

\section{Common positions / Union positions}

According to Article 29 TEU Lisbon version, the 'Council shall adopt decisions which shall define the approach of the Union of a particular matter of a geographical or thematic nature. Member States shall ensure that their national policies conform to the Union positions'. Although it offers the criterion that Union positions shall refer to a particular matter of a geographical or thematic nature,$^{48}$ the TEU lacks a detailed definition of this instrument. The wording of the Lisbon Treaty in respect of Union positions is identical to the provision on common positions in the Nice Treaty.

When turning to the question whether Union positions are binding on the Member States, it has to be mentioned that Article 29 TEU still falls short of offering the amount of information that the provisions on operational decisions do (Article 28 Lisbon version). The wording of Article 29 TEU that Member States 'shall ensure that their national policies conform to the Union positions' appears not to be as strict as the wording of Article 28 (2) TEU that stresses that operational decisions 'shall commit the Member States in the provisions they adopt and in the conduct of their activity'. However, there is still not enough substance to conclude that the difference in wording of operational decisions and Union positions should indicate, as an actus contrarius argument, that Union positions are not binding on the Member States. Rather, the use of the term 'conformity' implies that the Member States are under a negative as well as a positive obligation in respect of the conduct of their national foreign policy. On one hand, they are under the negative obligation to refrain from adopting any national foreign policy measures that would hinder the effect of existing or already anticipated Union positions. On the other

\footnotetext{
47 See Hillion and Wessel (n 43) 84.

48 Before the Treaty of Amsterdam, neither the Single European Act nor the Treaty of Maastricht offered even this rather vague condition.
} 
hand, they are under the positive obligation to modify their national foreign policy decisions that run counter to Union positions. ${ }^{49}$

In sum, Council decisions defining actions to be undertaken by the Union, as well as Union positions, are binding on the Member States. Their binding nature is enhanced by the principle of systematic cooperation and the principle of loyal cooperation. Once a Union decision has been adopted by the Council, the Member States are on the one hand under the obligation to actively support the Union's policy and on the other hand to refrain from any unilateral or multilateral action that could undermine the Union decision. Hence, the Member States are constrained in the conduct of their national foreign policies by secondary CFSP provisions once they have adopted these provisions through the Council.

\section{International agreements}

The Treaty of Lisbon explicitly states that Member States are bound by agreements concluded by the European Union in the sphere of the common foreign and security policy (Article 216 (2) TFEU in conjunction with Article 37 TEU). But what does this imply? What impact does the Union's competence to enter into international agreements have on the Member States? Will the Member States lose sovereignty to conclude international agreements with foreign and security implications once the Union has exercised its treaty-making competence, or will they retain the autonomy to do so, albeit with some constraints on the conduct of their national foreign policies?

Before the impact of Article 216 TEU on the Member States' national foreign and security policies is assessed, we should analyse whether Article $216 \mathrm{TFEU}$ is introducing something new or if the Member States are already bound by international agreements concluded by the European Union. The starting point for this analysis is the current Article 24 TEU of the Treaty of Nice. So far, the Council has concluded three types of international agreements in relation to the conduct of ESDP missions, including status of mission and status of force agreements with the host state, agreements with third parties, contributing personnel or assets, and finally agreements regulating exchange of information. ${ }^{50}$ Article 24 Lisbon version does not explicitly state that international agreements concluded by the Council on behalf of the Union are binding on the Member States. However, the wording of Article 24 (5) TEU, according to which agreements are not binding on a Member State that has made constitutional

\footnotetext{
49 See Hillion and Wessel (n 43) 85.

50 A Sari, 'The Conclusion of International Agreements by the European Union in the Context of the ESDP' (2008) 57 ICLQ 55.
} 
reservations in the Council, only makes sense if agreements are binding on Member States that have not made any reservations. ${ }^{51}$ Hence, international agreements of the European Union are already binding on Member States, and the Treaty of Lisbon is not introducing something entirely new in this respect. Nevertheless, the Treaty of Lisbon puts more emphasis on this fact.

But how far does this binding character go? Are the Member States still competent to conclude international agreements in the field of common foreign and security policy or have they transferred their treatymaking capacity to the Union and are prevented to conclude international agreements with a foreign and security implication? According to Article 3 (2) TFEU, the Union has

exclusive competence for the conclusion of an international agreement when its conclusion is provided for in a legislative act of the Union or is necessary to enable the Union to exercise its internal competence, or in so far as its conclusion may affect common rules or alter their scope.

But it can be questioned if agreements in the field of common foreign and security policy are likely to fulfil these requirements. Article 24 (1) TEU Lisbon version excludes the adoption of legislative acts from the scope of the common foreign and security policy. Hence, an international agreement in the sphere of the CFSP cannot be provided for in a legislative act of the Union. Furthermore, it is not obvious how the other conditions of exclusivity of Article 3 (2) TFEU can be met in a CFSP context. ${ }^{52}$ Hence, the Member States are not prevented from entering into international agreements, even if the Union has already exercised its competence.

The Member States might not have lost their treaty-making capacity to the European Union, but they could still be constrained by international agreements concluded by the Union in the conduct of their national foreign and security policy. Some go as far as to argue that EU agreements form an integral part of Union law by applying the Haegeman ${ }^{53}$ doctrine which has been developed by the ECJ in respect of Community agreements to EU agreements. ${ }^{54}$ Hence, they conclude that international agreements by the European Union would be able to bind the Member States in the same way as secondary CFSP provisions bind them. ${ }^{55}$ The

\footnotetext{
51 See Hillion and Wessel (n 43) 99.

52 See Hillion and Wessel (n 43) 104.

53 Case C-181/173 R\&V Haegeman v Belgian State [1974] ECR 449.

54 See Hillion and Wessel (n 43) 105; D Thym, 'Die völkerrechtlichen Verträge der Europäischen Union' (2006) 66 Zeitschrift für ausländisches öffentliches Recht und Völkerrecht 900.

55 See Thym (n 54) 901.
} 
Haegeman doctrine has been developed in relation to the Community legal order and one thus has to be careful before transferring its reasoning to the common foreign and security policy which is still treated separately from the Union under the Lisbon Treaty that is merging the former pillars of the European Union (Article 24 (1) subparagraph 2 TEU Lisbon version). Even if one does not apply the Haegeman doctrine, Article 216 TFEU, in conjunction with the principle of loyal cooperation as expressed in Article 24 (3) TEU Lisbon version, demands the Member States not to undermine existing EU policies. Thus, in cases where the Union has already concluded international agreements, they are not supposed to influence or even prevent the outcome of the agreement by engaging with others, or to adopt unilateral decisions. ${ }^{56}$ Furthermore, when the Union has not yet concluded international agreements but is anticipating doing so in line with an established Union policy and might have already entered into negotiations with third parties, the Member States have to refrain from concluding international agreements or from adopting unilateral acts that would run counter to the Union policy in order to protect the CFSP acquis.

In sum, although the Member States still have the competence to conclude international agreements and to adopt unilateral decisions, they are not entirely free to do as they please. The limits are set by EU law obligations. ${ }^{57}$ As a consequence of the principle of loyal cooperation, the Member States are not supposed to disturb the functioning of the institutional mechanisms and they are not entitled to adopt decisions that might undermine existing Union policies or that might even conflict with primary or secondary CFSP law. ${ }^{58}$

\section{v. Conclusion}

This analysis of the provisions of the common foreign and security policy leads to the conclusion that the European Member States are constrained by the Union's common foreign and security policy in the conduct of their national foreign policy. Whenever the European Union has previously been engaged in a topic related to the common foreign and security policy and has adopted a Council decision, the Member States are bound by this joint action/Council decision defining the action to be undertaken by the Union or by this common position/Union position,

\footnotetext{
56 A Dashwood, 'The Relationship between the Member States and the European Union/ European Community' (2004) 41 CML Rev 373.

57 B De Witte, 'The Emergence of a European System of Public International Law: the EU and its Member States as Strange Subjects' in J Wouters, A Nollkaemper and E de Wet (eds), The Europeanisation of International Law (TMC Asser Press, The Hague 2008) 46.

58 See De Witte (n 57) 46.
} 
as indicated by the wording and the systematic context of Articles 28 and 29 TEU Lisbon version. The binding nature of this secondary CFSP law is underlined by the primary CFSP principles of sincere cooperation (Article 32 TEU Lisbon version) and loyal cooperation (Article 24 TEU Lisbon version). The principle of loyal cooperation, containing the positive obligation for the Member States to actively support the Union's foreign and security policy, as well as the negative obligation to refrain from any action that might run counter to the Union's CFSP acquis, seems to be of greater significance than the principle of sincere cooperation that asks the Member States to consult one another in order for a Union decision to be made. In respect of international agreements concluded by the Union, the principles of loyal cooperation ask the Member States to refrain from influencing the effectiveness of the agreement by concluding agreements themselves or by adopting unilateral decisions.

However, the Member States are only constrained once they have voted in the Council and once the Council has adopted a secondary CFSP measure or concluded an international agreement on behalf of the European Union. However, no obligation exists to create a common policy in respect of certain issues. ${ }^{59}$ Thus, the Member States can avoid any constraints on the conduct of their national foreign policy by simply not putting a topic on the agenda of the Council, even if the topic concerns an issue of general interest to the Union. Furthermore, once a topic comes onto the Council agenda, they have the possibility to prevent a Council decision from being adopted. Although qualified majority voting has been introduced in the common foreign and security policy, the requirement for unanimity is still the rule. The Council can only act by qualified majority in cases where a former decision has been based on a unanimous vote (Article 31 TEU Lisbon version / Article 23 TEU Nice version). Matters falling under the European security and defence policy and having military or defence implications always require unanimous voting (Article 31 (4) TEU Lisbon version / Article 23 (2) TEU Nice version). Lastly, past practice has shown that the scope of joint actions and common positions is usually limited and thus leaves enough space for national policies. ${ }^{60}$ Under the Treaty of Lisbon, the existence of secondary CFSP norms will probably continue to not completely block the unilateral policy initiatives of the Member States in areas where the Union is also active.

The question if Member States can be constrained by the Union's common foreign and security policy when no secondary CFSP norms have been adopted so far is more difficult to answer. According to the

\footnotetext{
59 K Lenaerts and T Corthaut, 'Of Birds and Hedges: the Role of Primacy in Invoking Norms of EU Law' (2006) 31 EL Rev 301.

60 See Hillion and Wessel (n 43) 85.
} 
principle of loyal cooperation, the Member States are under the negative obligation to refrain from any action which runs counter to the interests of the EU or is likely to infringe its effectiveness. They have to respect the CFSP acquis. The acquis of the common foreign and security policy, however, is largely built up of secondary CFSP norms and international agreements. In consequence, the principle of loyal cooperation usually needs a substantive provision in order to assert its constraining influence on the Member States. However, once the CFSP acquis is build up, the principle of loyal cooperation asks the Member States not to adopt decisions that might undermine existing Union policies or that might even conflict with primary or secondary CFSP law.

In sum, the European Member States are constrained in the conduct of their national foreign policy by primary and secondary CFSP law, but only once secondary CFSP provisions have been adopted. But how strong are these constraints and how can they be enforced? The Lisbon Treaty does not introduce jurisdiction of the European Court of Justice in respect of the common foreign and security policy (Article 24 (2) TEU). It is for the Council and the High Representative to ensure the compliance of Member States with the principles of the common foreign and security policy (Article 24 (3) TEU Lisbon version). Hence, the Lisbon Treaty still falls short of introducing a strong enforcement mechanism. As a result, the constraints of the CFSP on the Member States appear to be legally weak. In a political sense, it might be more difficult for the Member States to pursue national policies that run counter to Union policies.

However, the constraints are of a legal nature and therefore indicate that some transfer of power from the Member States to the Union in the field of the common foreign and security policy has taken place. In consequence, the Member States are not just using the CFSP forum to exercise their national competences; the common foreign and security policy is not just about the pooling of sovereignty by the Member States to enhance their national external capacity, but rather about a transfer and a loss of sovereignty. Hence, the CFSP has developed into more than just the sum of its Member States. The legal constraints put on the Member States are probably not yet strong enough for the conclusion to be reached that they are 'semi-sovereign' or not 'fully sovereign states'. ${ }^{61}$ The Member States remain the dominant actors of the common foreign and security policy that can influence what is put on its agenda. As a result, no clear line can be drawn between the competences of the Union and those of the Member States in the common foreign and security policy. ${ }^{62}$ Perhaps it is more appropriate to talk about 'mixed sovereignty',

61 See De Witte (n 57) 49.

62 A Mignolli, The EU's Powers of External Relations' (2002) The International Spectator 109. 
indicating that at the international level external capacity is sometimes exercised by the Union, sometimes by the Member States and sometimes by both acting together. ${ }^{63}$ Hence, in respect of the relationship between the European Member States and the European Union in the field of the common foreign and security policy, as well as in the European security and defence policy, the Treaty of Lisbon does not clarify the situation and does not offer an approach different from that offered by the Treaty of Nice.

63 See De Witte (n 57) 50. 